\title{
Jakub Z. Lichański*
}

iD https://orcid.org/0000-0002-1943-5069

\section{The City of Man and the critique of fascism: The perspective of Hermann Broch}

Your name is a number, your story's a case, your need a request, your hopes will be filed, come back next week.

(Gian Carlo Menotti, The Consul)

Theatre relies on the public more than any other field of art [...] It must act at once or not act at all. (Hermann Broch, Theoretische Vorbemerkungen zum Manuscript ${ }^{1}$ )

Morals will have the primacy over economics, not economics over morals. The City of Man, New York, p. 58

\section{Introduction}

The City of Man initiative, a conscious reference even in its title to Saint Augustine's De civitate Dei, was deeply rooted in the desire to build a system that would ensure people's free and unfettered development after the First World War. The initiative was undertaken by both immigrants from Europe and eminent American intellectuals: they all hoped that a realized democracy in the classical Greek sense of the word would not only give us peace, but also open the perspectives

Professor emeritus, University of Warsaw, Institute of Applied Polish Studies, Chair of Rhetoric and the Media; e-mail: jakub.z.lichanski@gmail.com.

1 Unless otherwise indicated, all translations are those of the translator. 
that, among other things, had been closed by socialism in its fascist and Bolshevik variants ${ }^{2}$.

Why do I open, however, an article devoted to this somewhat forgotten initiative with remarks on Hermann Broch, who, though he played an important role in the work of this group, was simply "one of many" (exactly one of the seventeen members of the group)? This is due to the fact that his voice was weighty and not because this is my whim or due to the fact that I follow the suggestions of Paul Michael Lützeler, but because the issues raised in the manifesto of the aforementioned group were of great interest to the writer and philosopher from the very beginning of his activity, i.e. from his debut in 1931. It is therefore worth looking at how the artist solved the same problems, which he then "tried" to describe and analyze as a philosopher and theoretician of economics.

\section{Hermann Broch - a few facts}

Hermann Broch (1886-1951) ${ }^{3}$ is a writer and philosopher whose de facto absence from Polish literature and culture is difficult to explain. This is despite the fact that his major works were translated into Polish: The Death of Virgil (translated as Śmierć Wergilego by Maria Kurecka and Witold Wirpsza, Polish editions 1963 and 1993), Der Versucher [The Seducer] (translated as Kusiciel by Edyta Sicińska, Polish edition 1970), The Sleepwalkers (translated as Lunatycy by Sławomir Błaut, Polish

2 The City of Man. A Declaration on World Democracy, ed. G.A. Borgese, ed. 4, New York, The Viking Press 1941; P.M. Lützeler, "Donkiszotożuaneria. Hermann Broch o sobie samym", [in:] ibidem, Autobiografia duchowa, transl. S. Błaut, Czytelnik, Warsaw 2005, pp. 147-148; L. von Mises, Ludzkie działanie. Traktat o ekonomii, transl. W. Falkowski, Instytut von Misesa, Warsaw 2007, pp. 61-63, 224-225 nn., 606-608 nn.; P.M. Lützeler, Nur eine Weltdemokratie kann uns retten, http://www.tagesspiegel.de/kultur/nur-eine-weltdemokratie-kann-unsretten/4453704.html [accessed on: 17.02.2017].

3 Broch was trained as a textile engineer, he was a specialist in cotton manufacturing and a coowner of a patent on the cotton blending machine; he worked as a director a textile mill, was a chairman of the supervisory board of a spinning mill; he ran a military hospital (having done his military service), was a member of the Austrian Textile Industry Association and the industrial court mediatory board settling disputes amicably between workers and entrepreneurs (he received the title of counsel for this work). He was, however, chiefly a writer and philosopher whose position and significance in the history of literature, culture and philosophy of the 20th century are not to be overestimated. Broch's essays reveal him to be a philosopher struggling to preserve and perpetuate the traditional system of humanistic values which are deeply rooted in Plato's ideas and the Christian tradition, and also as a researcher of phenomena such as kitsch or contemporary novels. He believed that a work of art does not only have aesthetic values but also must perform ethical tasks. Cf. H. Arendt, "Einleitung", [in:] H. Broch, Dichten und Erkennen. Essays, Band I, Rhein Verlag, Zürich 1955 (Gesammelte Werke, Vol. 6, pp. 5-42). 
editions 1997 and 2005), The Guiltless (translated as Niewinni by Wanda Jedlicka, Polish edition 1961), Heimkehr des Vergil [The Return of Virgil] (translated as Powrót Wergilego. Opowiadania by Anna Maria Linke, Polish edition 1981) as well as an extremely modest collection of essays which consists of two short volumes: Notes on the Problem of Kitsch (translated as Kilka uwag o kiczu i inne eseje by Danuta Borkowska, Jan Garewicz, Ryszard Turczyn, Polish edition 1998) and Psychische Selbstbiographie [Mental Biograph] (edited by Paul Michael Lützeler, translated as Autobiografia duchowa by Sławomir Błaut, Polish edition 2005). These translations often did not attract much attention, failing to spark any bigger discussions or disputes. Also staging the monodrama entitled Zerline's Tale (Die Erzählung der Magd Zerline) in the Ateneum Theatre in 1992, starring the excellent Anna Seniuk, passed almost unnoticed. Hermann Broch's literary output also includes three "normal" plays: Die Entsühnung (1932), Als der Luft gegriffen oder die Geschäfte des Baron Laborde (1934) and Es bleibt alles beim Alten: Schwank mit Musik (1934), "a burlesque with music". Zerline's Tale may be found, however, among other plays in Hermann Broch's Archive at Yale University, which may come as a surprise. It is worth recalling that the French version of this monodrama was performed with great success by Jeanne Morreau (in the years 1986-1988); moreover, the monodrama was also put on in Germany in the 1980 os and in Poland in the 1990 .

As Maciej Ganczar recalled in his introduction to a recently published selection of plays ${ }^{4}$ :

[t]he first Polish theatre production is an adaptation of the short story Zerline's Tale (translated into Polish as Zwierzenia stużki Zerliny by Anna Maria Linke, directed by Kazimierz Kutza and staged in the Ateneum Theatre in Warsaw in 1992). Three years later Hermann Broch's prose inspires Krystian Lupa, who puts on Die Schlafwander. Esch; oder, die Anarchie (translated into Polish as Lunatycy. Esch, czyli Anarchia by Sławomir Błaut) in the Helena Modrzejewska National Stary Theatre in Krakow in 1995. He reaches out for another part of the novel in 1998, staging Die Schlafwander. Hugenau, oder die Sachlichkeit (translated into Polish as Lunatycy. Hugenau, czyli Rzeczywistość by Sławomir Błaut) in the same theatre. A year earlier Krystian Lupa puts on Dama z jednorożcem on the basis of Hermann Broch's short story entitled Hanna Wendling (translated by Sławomir Błaut) in the Polish Theatre in Wrocław and a short story by Robert Musil "The Temptation of Quiet Veronica" [Die Versuchung der stillen Veronika] (translated into Polish as "Kuszenie cichej Weroniki" by Zofia Rybicka). The short story Hanna Wendling directed by him is turned into a screen adaptation at the TV Theatre in 2001. Also Marek Fiedor uses Broch's pro-

$4 \mathrm{H}$. Broch, Rozgrzeszenie. Z powietrza wzięte. Dramaty, translation and introduction by M. Ganczar, Wydawnictwo ADiT, Warsaw 2010. 
se staging The Guiltless (transl. Wanda Jedlicka) at the Jan Kochanowski Theatre in Opole in 2000 and The Spell [Die Verzauberung] (translated as Oczarowanie by Edyta Sicińska) at the STUDIO Theatre Gallery in Warsaw ten years later.

Therefore Broch was known in Polish theatre yet again not so much for his original dramatic works as through stage adaptations of his prose works. What is more, I suppose it was not until his theatre plays had been published that we remembered that Broch is the author of a short yet very interesting essay "Theoretische Vorbemerkungen zum Manuskript" (Teoretyczne uwagi wstępne do "Rozgrzeszenia”), which, despite its somewhat misleading title, is in a way the writer's theatre credo. Theatre, or rather tragedy, is for the writer a kind of form of recognizing the human condition in the contemporary world; Broch sees the revival of theatre in a return to the "grand theatre", the theatre of human problems. He points here to the tradition of Sophocles; as this is all about placing man in the world, which is generally hostile to him, and where the Fate looms over humanity.

And indeed the position and importance of Broch in 2oth century literature, culture and philosophy are not to be overestimated.

The writer belongs, as was suggested as early as in the 1920 s by Franz Blei, to the five major literary figures in Austria, alongside Franz Kafka, Albert Paris Gütersloh, Robert Musil and Heimito von Doderer. His novels are extremely important in the history of shaping the world's modern prose; the pole position is obviously occupied by The Sleepwalkers and The Death of Virgil, with reference to which Witold Gombrowicz wrote terrible nonsense, unfortunately. The Sleepwalkers is a display of Broch's literary artistry which allowed him to combine a novel and a philosophical essay into a coherent linguistic whole, while encompassing a range of different styles, such as those typified in the novels of Theodor Fontane, Marcel Proust and James Joyce. The Death of Virgil, in turn, remains an unsurpassed model of the authentic epic, in the classical meaning of this word. This is not just a "tale about the last eighteen hours in the life of Virgil", but a sum of knowledge on the contemporary world, our fate, the discrepancy between ideals and the socalled normal life and about our destiny.

Two novels are vitally important for our reflections: Die Schlafwandler (The Sleepwalkers) (known in Poland as Lunatycy) and Der Versucher (The Seducer) as they both touch upon, surprisingly, problems concerning economics and politics, as well as rhetoric. In the former, contrary to appearances, the author is not content with the conventionally malicious picture of "the ruthless capitalist" (Hugonau), he also relies on certain "matter-of-factness" characterizing a certain way of thinking about economics and politics. The latter, in turn, deals perceptively with the problems in question, since it depicts how ideology is beginning to take over 
the good sense of the "economic" outlook on reality (here economics is understood as a person's attitude to economic issues, free from any ideological intrusions). Both novels, nevertheless, show - in an artistic mirror - issues connected with the human social behaviour.

A pessimistic outlook on life and the human condition in this world is connected with Broch's view on contemporary times, which he considered to be devoid of the feeling of stability. As Erich von Kahler said in his commentary to The Sleepwalkers, as early as the 1930s: "[...] our world [...] has lost its stability. This is a drifting world, a world of crisis, a world of permanent transformation." 5

The reason for this was the ongoing degradation of values, which was shown most vividly in his novel The Sleepwalkers. World War I put a definite end to this degradation and demise, yet beneath it was the ongoing breakdown of value systems and the omnipresence of the culture of kitsch (which was ingeniously described by, for instance, Wacław Berent in Próchno [Rotten Wood]). In his study entitled "Hugo von Hofmannsthal and His Time" (a fragment attached to the selection of plays) Broch shows how and why Europe at the end of the 19th century was becoming the "European value vacuum", which eventually had to lead to the catastrophe of war and the demise of the grand European tradition.

Broch's protagonists in his tragedies resembles a little the protagonists of his novels; as stressed by Maciej Ganczar:

The output of Hermann Broch the dramatist revolves around man dominated, if not enslaved, by the world of economy, which makes us merely its puppets. Consequently, it takes away the pole position from politics. In a world governed by economic principles there is no room for emotions and feelings. This is a man's world, they usually do not live up to challenges they are faced with, and they see their salvation in suicide, or an escape from problems in the world of fantasy and memories. Broch's world of economics is the world of machinations, or plots fueled by men, as he depicts it in his comedy Aus der Luft gegriffen oder Die Geschäfte des Baron Laborde. Women in Broch's plays appear somewhat on the margin from which they look at men's struggles. But they are ready any minute to receive them, listen to them, understand and love them. The world depicted in Broch's tragedies is a world of the eternal struggles of different parties for survival but also privileges. This incessant struggle for survival, tossing and turning in economic mechanisms, is stopped from time to time by a temporary crisis which demands victims in the form of human life.

5 Cited in: M. Durzak, Hermann Broch, Rowohlt Verlag, Frankfurt am Main 1966; also J.Z. Lichański, Hermann Broch, Wydawnictwo Naukowe Semper, Warsaw 1994, p. 15.

6 See: H. Broch, "Hofmannsthal i jego czasy. Studium", [in:] ibidem, Rozgrzeszenie..., pp. 185-191 (transl. R. Turczyn). 
In turn, Broch's scientific works devoted to the psychology of masses/the crowd (or, as we tend to put it now, the psychosis of the masses) and political problems, or his philosophical studies, are practically unknown in Poland. And it is worth enumerating at least those subjects which were of interest to him and which he wrote about, including: practical work and military service, the theory of values, the theory of the League of Nations, the theory of democracy, economic impetus for the City of Man and finally the theory of the psychosis of the masses. ${ }^{7}$ It was not until recently, however, that Broch's scientific studies were analyzed more in depth; these are works by Paul Michael Lützeler, Monika Kluger, Thomas Eicher, Hartmut Steinecke and Manfred Welan. ${ }^{8}$ Let us focus, however, on the City of Man, since information on this initiative is, to say the least, scarce.

\section{The City of Man - introduction}

The term "the City of Man" needs to be explained; as Broch says: "[this was] a group whose aim was to research the conditions of re-strengthening the democratic thought and casting light on them, taking into account all possible aspects [...]."9 Its leader was Giuseppe Antonio Borgese, an Italian writer and journalist, opponent of fascism, who emigrated to the US and was professor at the University of Chicago. Apart from Broch, the group included, for instance: Thomas Mann, William Yandell Elliot, a historian and political advisor of six US presidents; Frank Aydelotte, the director of the Institute for Advanced Study (1939-1947); Christian Gauss, a linguist and literary scholar, one of Woodrow Wilson's tutors; and Alvin Johnson, the founder and director of the New School of Social Research in New York $^{10}$. The efforts of the scholars centred around it led to the publication of

7 Some scholars use the term "madness of crowds".

8 P.M. Lützeler, "Donkiszotożuaneria...", pp. 150-151; Th. Eicher, P.M. Lützeler, H. Steinecke, Hermann Broch. Politik, Menschenrechte- und Literatur, Athena Verlag, Oberhausen 2005; M. Welan, Das Menschenrecht Hermann Brochs, WPR, Wien 2004 (Disskusionpapier 2004, No. 102-R-04).

9 H. Broch, Autobiografia..., p. 89; P.M. Lützeler, "Donkiszotożuaneria...", pp. 147-148. Also important remarks in: D.L. Wallace, The Death of Civilization. Ethics and Politics in the Work of Hermann Broch, University of California, San Diego 2006, p. 82 nn. (doct. diss.); cf. also P.M. Lützeler, Nur eine Weltdemokratie kann uns retten, http://www.tagesspiegel.de/kultur/ nur-eine-weltdemokratie-kann-uns-retten/4453704.html [accessed on: 17.02.2017].

10 The aforementioned P.M. Lützeler describes in detail the group's composition and activity in the cited paper: "Diese Gruppe traf sich zu zwei Arbeitstagungen vom 24. bis 26. Mai 1940 in Atlantic City (New Jersey) und vom 24. bis 25. August 1940 in Sharon (Connecticut). Den Sitzungen gingen Einladungen mit genauen Arbeitsplänen voraus, ihnen folgten briefliche und telefonische Abstimmungen. Im November 1940 erschien das Ergebnis, „The City of 
The City of Man. A Declaration on World Democracy in 1940, which was reissued four times.

It is worth quoting the opinion of the aforementioned Paul Michael Lützeler, who years later would describe the project called The City of Man ${ }^{11}$ in the following way:

Was sind die Forderungen der "City of Man“? Die USA, heißt es, müssten mit ihrer demokratischen Staatsform eine humane Alternative zum Terror Hitlers bieten. Wie jene Europas befinde sich aber auch die Demokratie Amerikas in einer tiefen Krise, und nur eine erneuerte Demokratie sei in der Lage, dem Totalitarismus entgegenzutreten. Amerika solle sich für folgende Ziele einsetzen: Im Gegensatz zur Kriegsverherrlichung der Nazis sei das Postulat des universalen Friedens zu verteidigen. „Die Demokratie lehrt“, heißt es, „dass alles durch, nichts gegen und nichts außerhalb der Menschlichkeit zu geschehen hat. Die Diktatur der Humanität auf der Basis des Gesetzes zum Schutz der Menschenwürde ist die einzige Herrschaft, von der die Hoffnung für unser eigenes Leben ausgeht und von der die Wiedererstehung jener Nationen zu erwarten ist, die sich an der Humanität vergingen."

Die Aufgabe der USA bestehe darin, die Welt für eine neue Ordnung zu gewinnen. Freilich könne das jetzige Amerika diese Rolle noch nicht übernehmen. Zu den „Fehlern, welche die Erfüllung ihrer Aufgaben gefährden“, werden gezählt: „die geringgeschätzte Bildung, die korrupte Politik und die öde Effizienz der Spekulanten“. Amerika müsse sich besinnen: „Die amerikanische Verfassung muss Wirklichkeit werden." In diesem Zusammenhang wird postuliert: Erstens müssten in einer Verfassungsreform die Rechte und Pflichten des Einzelnen dem Staate und des Staates dem Einzelnen gegenüber genauer formuliert werden. Zweitens sei die Trennung von Kirche und Staat klarer herauszustellen. Drittens seien Wirtschaftsreformen anzustreben, welche die Ansätze des New Deal weiterführen. Viertens sei ein internationales Gesetzbuch auszuarbeiten. Nach diesen Reformen könne, sobald Hitler besiegt sei, auch das Projekt einer Weltdemokratie mit einer Weltverfassung angestrebt werden. Das war ein Lieblingsgedanke Borgeses.

Die Wirkung einzelner Bücher ist schwer einzuschätzen. Jedenfalls leistete das Intellektuellen-Konzil etwas, dem man Realitätstüchtigkeit nicht absprechen kann: Es trug dazu bei, in der amerikanischen Öffentlichkeit eine Bereitschaft zu schaffen, militärisch gegen Hitler vorzugehen und nach dem Krieg die demokratische Staatsform im europäischen Einflussbereich der USA durchzusetzen. Mit seinen universalistischen Perspektiven wurde bereits fünf Jahre vor der Etablierung

Man. A Declaration on World Democracy", bei der Viking Press." (P.M. Lützeler, Nur eine Weltdemokratie...).

11 Ibidem. 
der Vereinten Nationen und acht Jahre vor der Verkündung der Internationalen Menschenrechte die globale Durchsetzung demokratischer Grundsätze ins Auge gefasst. Es war eine Pionierarbeit. [...]. [What are the assumptions of "the City of Man"? The USA, as it is said in this document, should create a human alternative of a democratic state to the proposal offered by Hitler's terror. Like in Europe, democracy in America is in deep crisis, yet only renewed democracy is capable of opposing totalitarianism. America should strive to achieve the following goals: it has to defend the postulate of universal peace as opposed to the glorification of war by the Nazis. "Democracy teaches", as we read in the declaration, that "everything must be within humanity, nothing against humanity, nothing outside humanity. The dictatorship of humanity, on the basis of a law for the protection of human dignity, is the only rule from which we may hope for life for ourselves and resurrection for the nations that have fallen".

[The task of the US will be to conquer the world for the new order. Naturally, it may be said that current America cannot take on this role. "The blemishes that endanger the fulfillment of her tasks" include "the degraded education, the corrupted political machines, the efficiency of the dollar-hunter". America must remember that: "the American constitution may become reality." As a result, firstly, constitutional reform is demanded, in which the rights and obligations of the individual be adjusted to the given state, but also the state should define its duties towards individuals in greater detail. Secondly, the separation of church and state should be clearly stated (clearly defined). Thirdly, economic reforms should be accomplished in such a way as to use the experiences known from the New Deal. ${ }^{12}$ Fourthly, the international code (of

12 The problem of assessing the New Deal is rather complex. It is often pointed out that it is not easy to evaluate the consequences of the New Deal. It is commonly believed that it brought about an improvement in the economic situation and contributed to an increase in the standard of living of American society. President Roosevelt's policy met, however, with harsh criticism from the liberal circles. Most of all, the issue of its huge costs was raised. The comprehensive measures taken as part of the New Deal triggered an increase in global demand. It is particularly worth stressing its humanitarian aspect, which was manifested predominantly in the social sphere. Assistance granted to the unemployed increased their spending power, which enhanced the country's economic activity. The Public Works Administration constructed 122 thousand public buildings, over 1 million km of roads, 77 thousand bridges and 285 airports. In 1933 the government spent 500 million dollars on helping the unemployed. By 1942 the administration had spent 13 billion dollars on public works. As a huge experiment, the New Deal helped the capitalist economy to reach maturity. Changes in legislation, the transformation of financial and credit institutions, increasing the supervisory functions of central authorities - all these actions brought positive social and economic consequences in the years to come. And, most importantly, there was an improvement in the social atmosphere and increased trust inthe state, institutions and entrepreneurs. 
cooperation) should be elaborated. After these reforms maybe one day Hitler will be defeated and the project of world democracy and global constitution will be put into practice. This was Giuseppe Antonio Borgese's favourite idea.

The impact of individual books is difficult to evaluate. Anyway, the Council's intellectuals contributed to something which undeniably "gave impetus" to the reality: it may have contributed to creating some readiness in American society to undertake military activities against Hitler and enforcing democratic rule in the US sphere of influence in Europe after the war. Surely its universal perspective helped to implement democratic principles globally five years before the United Nations came into being and eight years before the announcement of international human rights. This was pioneering work. [...]]

What was Broch's contribution to this project? He stressed already at that time that in economics it was necessary to initiate a dispute with socialism (for him Russia was the embodiment of international power of socialism). Broch drew attention to the fact that socialism, contrary to appearances, does not accept democracy, as "[...] in the case of either a Nazi or radically socialist victory, the firing squad will be waiting for the defenders of democracy."13

This sentence, uttered in 1940, received its terrifying confirmation a few years later. It suffices to say that in his study Human Action. A Treatise on Economics (1949; third modified edition 1966) Ludwig von Mises, an eminent Austrian economist, attempted to analyze socialism as an economic proposal in a systematic way and indicated what havoc it wreaks in both economic and, even more importantly, social life.

The writer's subsequent ruminations show a very disturbing phenomenon, which we know all too well, as man turns from being a subject into being the object of activities by the state obsessed with the idea of socialism, especially communist breeding. It is also important to point to Hermann Broch's remark on the theory of

The New Deal temporarily stopped the negative consequences of the economic crisis, yet it failed to prevent another recession in 1937 (this time the Cabinet of the United States intervened decisively, through lowering interest rates and extending the programme of public works). Yet after this, especially because of World War II, the country entered a path of long-term economic growth. Roosevelt gained widespread public support and was re-elected three times in 1936, 1940 and 1944. The New Deal opponents pointed to the fact that some investments within this programme were initiated still by Hoover. One of Roosevelt's closest associates admitted later that "practically the whole New Deal was extrapolated from programs that Hoover started." The achievements of the New Deal inspired John Maynard Keynes to devise the concept of state interventionism in his work The General Theory of Employment, Interest and Money (1936). Cf. https://mfiles.pl/pl/index.php/New_Deal [accessed on: 17.02.2017]. 
value as it suggests that there are no major discrepancies between environmental and humanistic cognition. He based his reflections on the assumption that ${ }^{14}$ :

[...] there are "deeds" of I (or man) and these deeds lead to "results" (to formations of the world), that should be both included in the category of values as a result of certain epistemic assumptions which, in turn, may be justified by the function of aiming for truth characteristic of thinking and that [...] the first one is subject to "ethical evaluation" whereas the latter - the "aesthetic one", despite the fact that it is impossible to ever separate the two category aspects.

This way of thinking seems to be worth not only noting but also investigating further. As Broch himself says, "original works were mostly damaged as a result of the detention and inspection conducted by the Gestapo"15. Thus his words about the fate of those who struggle for freedom and democracy came true in the case of the writer.

\section{Presentation of the problem}

The monumental study by Ludwig von Mises, Human Action, refers to a number of issues, the most important of which are connected with economics. For me, however, the most interesting problems in his work concern attempts to analyze the reasons why people take certain decisions, as this is the place where the two scholars meet. As the views of von Mises are well known, these issues will only be outlined from the perspective of Broch the writer and philosopher.

Before outlining Broch's views, it is worth analyzing one extremely important fragment from the work by von Mises. He draws attention to the fact that ${ }^{16}$ :

There are two patterns for the realization of socialism.

The first pattern (we may call it the Lenin or the Russian pattern) is purely bureaucratic. All plants, shops, and farms are formally nationalized (verstaatlicht); they are departments of the government operated by civil servants [...].

The second pattern (we may call it the Hindenburg or German pattern) nominally and seemingly preserves private ownership of the means of production and keeps the appearance of ordinary markets, prices, wages, and interest rates. There are, however, no longer entrepreneurs, but only shop managers (Betriebsführer in the terminology of the Nazi legislation). [...] But in all their activities they are bound to obey unconditionally the orders issued by the government's supreme

14 Ibidem, pp. 68-69.

15 Ibidem, p. 79; P.M. Lützeler, “Donkiszotożuaneria...”, pp. 141-142.

16 L. von Mises, The Human Action..., pp. 606-607. 
office of production management. [...] This is socialism under the outward guise of the terminology of capitalism [...]. It is necessary to point out this fact in order to prevent a confusion of socialism and interventionism. The system of interventionism or of the hampered market economy differs from the German pattern of socialism by the very fact that it is still a market economy. [...] The system of the hampered market economy or interventionism aims at preserving the dualism of the distinct spheres of government activities on the one hand and economic freedom under the market system on the other hand.

As we may see, therefore, socialism, as a certain economic proposal, leads to an acute conflict between the state and the individual, as was pointed out by Broch. Hence the problem to be described here is clear: this is the fundamental conflict between man and his free decisions as one of the sources of disparate reflection, including, on the one hand, on economics, but, on the other, a priori ideological assumptions ${ }^{17}$ which, in summa, deprive man of the freedom of decision. The reason for this second situation may be found in external factors, mainly in the breakdown/decline of values, yet the source of it is, to a large extent, in ourselves. Broch portrays an artistic vision of this issue in nearly all his novels and plays. The writer seems to suggest that the personal responsibility of the protagonist in a work of art and his freedom of decision become a model of behaviour for the masses, and the work of art is supposed to remind us of the importance of this model. This issue is depicted most powerfully in the heated discussion between Virgil and Augustus in part three of The Death of Virgil.

In his novels Die Schlafwandler and Der Versucher / Die Verzauberung Broch analyzes situations in which people lose the freedom to decide, due to the influence of somebody or something, or in which that freedom is taken away from them, e.g. by force, or finally, situations where there is a mixture of these two "ways" of losing freedom. Yet, according to Broch, each of these situations also often results from the fact that the individual / subject loses the sense of durability or of being rooted in a stable system of values, since according to the writer the sine qua non condition of freedom is at the same time its voluntary restriction, perhaps connected with the Platonic-Christian idea of kalokagathia.

Both novels show protagonists in situations where, having lost the feeling of stability, they are forced to take decisions which in many cases are of fundamental

17 Cf. S.K. Foss, Rhetorical Criticism: Exploration and Practice, Waveland Press Inc., Long Grove, III. 2004, p. 239 [she refers mainly, but not solely, to the concept of Teun van Dijk]: ideology is "a set of beliefs which determine interpretations of certain aspects of the world by a certain group. These beliefs express the fundamental social, economic, political and cultural interests. They represent: "who we are, what we support, what we represent and what our relations with other groups are like". 
importance. The protagonists of both Die Schlafwandler and Der Versucher / Die Verzauberung look to ideology to provide grounds for the decisions which will change their lives. Only those who live in freedom are capable of taking such decisions in a proper way which does not violate anyone's freedom. Consequently, Esch must die [he threatened, by accident, the "matter-of-fact" Huguenau], the same goes for the beloved of the narrator of Der Versucher / Die Verzauberung, who becomes misled by the communist ideology and dies during an unsuccessful putsch [this is based on the authentic putsch in Vienna in 1934], and the peasants of Kuppron fall into the trap of Marius, who lures them with a mirage of getting rich easily. This happens due to the fact that: "Morals will have the primacy over economics, not economics over morals."18

When one forgets about this principle, one may fall into the hands of someone who, like Marius from Der Versucher / Die Verzauberung, resorted to many clichés, but in reality wished to become a member of the local council. Both novels warn that democracy and monarchy are equally prone to abuse, especially when they are not deeply rooted in a stable system of clearly defined values. How does this refer to the issue of economics? If this is perceived narrowly, mainly as a practice of running a household, then not much, in fact. But if we look at it from a broader perspective, as both the theory and practice of each of us taking decisions which lead to serious changes in both our situation in the world and in the world itself, then the issues indicated by Broch take on a fundamental significance. The peasants of Kuppron, Esch, or the beloved of the narrator of Der Versucher / Die Verzauberung take decisions which de facto put an end to their self-reliance, take away their freedom and, in the case of at least two of them, lead to self-destruction.

\section{Economy - Literature - Philosophy}

I will begin by quoting a bitter comment by Broch which explains why both communist and fascist ideas win so easily ${ }^{19}$ :

For a socialist, especially of communist provenance (same as for a fascist), this democratic freedom is nothing but sheer hypocrisy, luxury for the possessor and a useless adornment for the poor, [...] as man needs economic security and fulfilment of emotions, but does not need freedom; it will be possible to talk about freedom one day when there is classless [society] and each stomach is full.

It is worth remembering that the author of these words also dealt with the issue of the psychosis of the masses and the aforementioned reflection is also probably

18 The City of Man..., p. 58.

19 H. Broch, Autobiografia..., p. 90. 
partially a result of that research. When we consider, therefore, strictly economic issues it is necessary to pay attention not only to man's space of freedom but, above all, to teach this man to use this "space of freedom". Only then is it possible to accomplish what Broch called a "decapitalized private economy". The writer is, however, a realist and he sees the first stage of work which is supposed to take years simply in the acceptance of private economy, and the state's activity should consist in inhibiting big business. It must be remembered, however, that Broch's analyses concern the 1940s when, on the one hand, the positive effects of Roosevelt's New Deal were clearly visible and, on the other, the bright picture of the economic situation in both the US and the world obscured the economic growth resulting from the upturn in the economy caused by the war.

Yet the outlook of the City of Man members on issues concerning democracy is more important ${ }^{20}$ :

[...] Universal and total democracy is the principle of liberty and life which the dignity of man opposes to the principle of slavery and spiritual death represented by autocracy. [...] Democracy, therefore, is an ancient hope of man calling for fulfillment in the coming age of man. Its unity rests upon three principles.

The first is universal participation in government, through the direct expression of referendum or town meeting, or through electoral mandate, or even-when the stress of the times so commands-through the delegation of all authority to a responsible chief executive freely chosen by the people for a limited term. This is the government of the people by the people, the foundation of law.

The second principle emphasizes that the state is the agent of collective human purposes, the servant of the common good, and that the demos, the unity of the people, is the permanent source of power behind those who temporarily hold it. Therefore a democracy must be always ready to rise not only against the selfappointed usurpers of power, but "against the never-ending audacity of elected persons" as well. This is the government of the people for the people, the foundation of equality.

The third principle, fundamental to the other two, establishes that a democratic community is a community of persons. Democracy, therefore, cannot be run by robots and automatons, by serfs and slaves. Its vigor rests upon the cultivation and discipline of the person, as a self-acting and self-controlling agent. Its quality is the quality of the education which it imparts to its citizens and exacts from them, in the balance of private interest and public service that makes the substance of the social contract. This is the foundation of justice. 
These simple principles are, however, very difficult to implement, as the period following World War II demonstrates. This is due to the fact that both Broch and the other members of the City of Man pointed out a certain problem which is connected with democracy, for ${ }^{21}$ :

[democracy has] Janus faces [...] From its principle of freedom democracy looks toward capitalism, which it envisions as natural, even if not unqualifiedly necessary; while from its principle of justice democracy looks toward collectivism, which it considers as necessary, even if not so conformant to nature.

It is particularly important to see that the "naturalness" of capitalism is far from obvious (this results from, among other things, the fact that a definition is needed of what is understood by capitalism, and as analyses show, this is not so obvious; see the comments of the authors of the City of Man on the New Deal). Also the second observation is essential; the principle of fairness which is connected with equality and, consequently, certain understanding of collectivism, is not natural in itself. This is not about legal matters, as the principle of equality may not be questioned; in social life, however, collectivism is not a good principle and we experienced its rather terrifying consequences in the years of the People's Republic of Poland. It is interesting to see the following comment of the manifesto authors: ${ }^{22}$

Man, recovering from his guilty blindness, must become aware at last that the problem of production, which was a problem of power, has been virtually superseded by the problem of distribution, which is a problem of justice [...]. Economy can be pluralistic and flexible, with its primary centers transferred from the metropolitan cities to the villages, close to the friendlier suggestions of nature. Federal aggregations $[\ldots]$ could collect around focal points the energies radiating from the smaller communities.

The authors argue that the matters of production, distribution, fairness and power are closely connected with one another. It is also striking to see the concern about ecology and the indication that the bond between workers (trade union members) and local communities should be strong and mutual. ${ }^{23}$ The authors go on to stress that it is only the development of democracy that will ensure the freedom of individuals and guarantee that economics will not be subordinated

21 Ibidem, p. 90.

22 Ibidem, pp. 56-57.

23 I suppose the indicated solutions were probably suggested by Broch, who used his own experience, see note 2 . 
to any ideology. ${ }^{24}$ The economy understood as an uninhibited activity of man ${ }^{25}$, as Broch argued a few years before Popper, should belong to an open rather than closed social system.

When we talk about democracy one should remember about the indicated dangers and steer clear of them. These issues were most comprehensively analyzed by Hans-Hermann Hoppe and it is worth looking more closely at his comments. ${ }^{26}$ He points to, what are, in his view, important limitations of democracy; some of them are also addressed by Broch. Hoppe, however, presents a very important limitation which threatens democracy, in his opinion. One of them is the imminent concentration of power in democratic systems: ${ }^{27}$

In contrast to the internal and external moderation of a monarchy, a democratic (publicly owned) government implies increased excess, and the transition from a world of kings to one of democratically-elected presidents must be expected to lead to a systematic increase in the intensity and extension of government power and a significantly strengthened tendency toward decivilization.

Hence, in Hoppe's opinion, democracy will not be the fulfilment of hope, as it is threatened by exactly the same things which were indicated by the authors of the City of Man. Thus does democracy have to fail as well? Probably not, and here Broch enters with his positive proposal. Being fully aware of the aforementioned limitations of the description of the current economic situation, Broch sees the essence of this project in two proposals: ${ }^{28}$

[...] firstly, is it possible that the scientific analysis of the phenomenon of crisis and its history will point to a new way (different from communist or fascist solutions) leading to liberation from crisis?

Secondly, having adopted this assumption, is it possible within the democratic system to win over social groups which are sufficiently strong politically to accomplish it?

The first one has been partially solved (I believe that von Mises's work plays an important role here), yet the latter, at least partly, is still a task for us. ${ }^{29}$

24 The City of Man..., pp. 57-58 nn.

25 L. von Mises, The Human Action...

$26 \mathrm{H} .-\mathrm{H}$. Hoppe, Democracy. The God that Failed. The Economics and Politics of Monarchy, Democracy, and Natural Order, transl. W. Falkowski, J. Jabłecki, Fijorr Publ., Warsaw 2005.

27 Ibidem, p. 30.

28 H. Broch, Autobiografia..., p. 100.

29 Ibidem, pp. 69-70, 87; P.M. Lützeler, “Donkiszotożuaneria...”, pp. 141, 147. 
In addition, the City of Man includes two excellent remarks concerning the relation between ethics/morality and economy: "Morals will have the primacy over economics, not economics over morals [...] A real Realpolitik is applied ethics."30

This last remark is of great importance since failing to take into account ethics in politics (and, consequently, in economics) leads, or may lead, to put it cautiously, to unfortunate consequences.

These issues were also presented by Broch in his plays; using his professional experience he shows in Die Entsühnung certain economic mechanisms and their impact on man, especially in a crisis situation. The Filsmann factory must undergo restructuring, as we would put it today; this means redundancies, which sparks protest among workers and trade union members who represent them. The protest becomes only a means for achieving the goal, i.e. power over the masses; this will be ensured by spreading panic. Here Broch is considering the theory of mass madness, which was developed later. Murdering the chairman of the shop council becomes a way of causing panic; it is perceived not so much as a crime as a factor causing panic, hence as a blessing for the future leader.

The drama Als der Luft gegriffen oder die Geschäfte des Baron Laborde is a picaresque comedy which, leaving aside the plot of deceitful pseudo-businesses, in reality focuses on love affairs. The plot revolves around a crisis which affects almost all protagonists, and the reason for it is, naturally, the lack of money. Each of them tries to commit suicide in an extremely inept manner. As Grażyna Kwiecińska writes, the play's innovative character does not consist so much in placing the stock exchange in the play as in noticing how detached it is from the real and material world. ${ }^{31}$ Broch makes a reference in his play to one of his main themes: the fall of the bourgeois. Against the background of slightly grotesque farce based on love affairs, the writer shows a kind of parallel plot consisting of stock exchange intrigues, speculations on equity using gossip and alleged transactions, falsified promissory notes or dealing in worthless shares. All this, as Maciej Ganczar says, is at the expense of other shareholders. The last element in this chain is the state, which is ready to make a sacrifice (or rescue bankrupts). But also society seems to accept fraud since, as the director of the hotel where the action takes place says: "We always tolerate a few eccentric figures who absorb the guests' fantasies".

Thus Broch remained, also as a playwright, loyal to his main topics, which include: the breakdown of the European culture, the fall of the bourgeois and the demise of values. But also, as he says in The Guiltless, "pushing away any responsibility for one's life". As well as, let us add teasingly, economics, and all these topics are interwoven with one another into an tangled knot.

30 City of Man..., pp. 58, 88.

31 G. Kwiecińska, Hermann Brochs Engagement für die Demokratie, Literatur und Politik, Ekochem - Agencja Poligraficzno-Wydawnicza, Warszawa 1999. 


\section{Conclusion}

"Beautiful tradition finished", he wrote in his poem from the cycle Voices 1913. He was looking for something which would allow him and us rebuild the shaken sense of the world's stability; I suppose it was the belief that, as he said in his essay "Leben ohne Platonische Idee" [Life without the Platonic Idea], reason and freedom are inseparably connected. And life without kalokagathia, the Platonic idea, is impossible. In his plays, perhaps with the exception of Es bleibt alles beim Alten: Schwank mit Musik, he also remained faithful to this message. This is why in the ending of The Atonement he lets women speak, and Old Mother, whose speech crowns the play, says:

we, voices of the future, carry stars,

we call the farthest distance,

we call unity that we feel,

oh, see the divine circle of love.

In conclusion, a seemingly banal truth may be told: the freedom of decision has been always extremely inconvenient for "the great skippers"; the dream of all tyrants is perfectly expressed by the quotation opening these reflections from the opera libretto by Gian Carlo Menotti. An analysis by Broch and his companions from the City of Man ideally complements the penetrating description by Mises. It shows, in an artistic nutshell, the consequences of violating the foundations of free will in the social behaviour of man.

The causes of the crisis may be found, according to Hermann Broch, in the fact that the system of values, with its twofold foundations: religious and philosophical, as well as economic and political, lost its stability. This was accompanied by the disappearance of the sense of freedom in social life for an individual. At the same time the writer sees a threat of "extortion" with regard to stability in social life through different forms of the state's enslavement of man.

Yet, according to Broch, man's personal freedom is threatened not so much by the breakdown of the stability of the previous value system (e.g. resulting from external pressures) as by the lack or decay of the sense of connection with this system in an individual; "life without the Platonic idea" turns out to be impossible, in fact. This is due to the "spiritual laziness the result of which is not only disappearance of individual responsibility for anything but also, most importantly, waiting for Messiah to arrive and do something for us." ${ }^{2} 2$ The latter represents all of our voluntary resignations from personal responsibility, both for our deeds and their

32 H. Broch, Kilka uwag o kiczu i inne eseje, translation in collaboration, Czytelnik, Warszawa 1998, p. 166 (selection from vol. 9.1-2, and 10.1 Kommentierte Werkausgabe). 
consequences [Broch describes this problem in detail in both The Sleepwalkers and The Guiltless].

At this point, von Mises and Broch meet - they both assign quite an easy task for us - we cannot let ourselves resign from our subjectivity, since as Broch reminds us "freedom and reason are always chained to one another." 33

\section{Bibliography}

Arendt Hannah, "Einleitung", [in:] H. Broch, Dichten und Erkennen. Essays, Band I, Rhein Verlag, Zürich 1955 (Gesammelte Werke, Vol. 6, pp. 5-42).

Broch Hermann, "Hofmannsthal i jego czasy. Studium", [in:] Hermann Broch, Rozgrzeszenie. $Z$ powietrza wzięte. Dramaty, translation and introduction by M. Ganczar, Wydawnictwo ADiT, Warsaw 2010, pp. 185-191 (transl. R. Turczyn).

Broch Hermann, Kilka uwag o kiczu i inne eseje, translation in collaboration, Czytelnik, Warszawa 1998 (selection from vol. 9.1-2, and 10.1 Kommentierte Werkausgabe).

Broch Hermann, Rozgrzeszenie. Z powietrza wzięte. Dramaty, translation and introduction by M. Ganczar, Wydawnictwo ADiT, Warsaw 2010.

Durzak Manfred, Hermann Broch, Rowohlt Verlag, Frankfurt am Main 1966.

Eicher Thomas, Lützeler Paul M., Steinecke Hartmut, Hermann Broch. Politik, Menschenrechte- und Literatur, Athena Verlag, Oberhausen 2005.

Foss Sonja K., Rhetorical Criticism: Exploration and Practice, Waveland Press Inc., Long Grove, Ill. 2004.

Hoppe Hans-Hermann, Democracy. The God that Failed. The Economics and Politics of Monarchy, Democracy, and Natural Order, transl. W. Falkowski, J. Jabłecki, Fijorr Publ., Warsaw 2005.

https://mfiles.pl/pl/index.php/New_Deal [accessed on: 17.02.2017].

Kwiecińska Grażyna, Hermann Brochs Engagement für die Demokratie, Literatur und Politik, Ekochem - Agencja Poligraficzno-Wydawnicza, Warszawa 1999.

Lichański Jakub Z., Hermann Broch, Wydawnictwo Naukowe Semper, Warsaw 1994.

Lützeler Paul M., "Donkiszotożuaneria. Hermann Broch o sobie samym”, [in:] Paul M. Lützeler, Autobiografia duchowa, transl. S. Błaut, Czytelnik, Warsaw 2005.

Lützeler Paul M., Nur eine Weltdemokratie kann uns retten, http://www.tagesspiegel.de/kultur/nur-eine-weltdemokratie-kann-uns-retten/4453704.html [accessed on: 17.02.2017]. 
Mises Ludwig von, Ludzkie działanie. Traktat o ekonomii, transl. W. Falkowski, Instytut von Misesa, Warsaw 2007.

The City of Man. A Declaration on World Democracy, ed. G.A. Borgese, ed. 4, New York, The Viking Press 1941.

Wallace Donald L., The Death of Civilization. Ethics and Politics in the Work of Hermann Broch, University of California, San Diego 2006.

Welan Manfried, Das Menschenrecht Hermann Brochs, WPR, Wien 2004 (Disskusionpapier 2004, No. 102-R-04).

Jakub Z. Lichański

\section{The City of Man i krytyka faszyzmu: perspektywa Hermanna Brocha}

\section{Streszczenie}

Inicjatywa The City of Man, mimo świadomego odniesienia do dzieła Świętego Augustyn De civitate Dei, pragnęła, aby po wojnie zbudować system, który zapewniłby wolny i nieskrępowany rozwój ludzkości. Inicjatywę tę podjęli emigranci z Europy i wybitni amerykańscy intelektualiści: wszyscy mieli nadzieję, że urzeczywistniona demokracja w klasycznym greckim znaczeniu tego słowa nie tylko da nam pokój, ale otworzy także perspektywę, która, między innymi, zlikwiduje socjalizm w wersjach faszystowskich i bolszewickich.

Dlaczego jednak artykuł poświęcony tej, dzisiaj nieco zapomnianej inicjatywie, otwieram uwagami na temat Hermanna Brocha, który choć odegrał ważną rolę w pracy tej grupy, był po prostu ,jednym z wielu” ( dokładnie jeden z siedemnastu członków grupy)? Wynika to z faktu, że jego głos był ważki. Podążam także za sugestiami Paula Michaela Lützelera; trzeba pamiętać, że kwestie poruszone w manifeście wspomnianej grupy, zostały podjęte przez pisarza i filozofa, od początku jego działalności, czyli od debiutu w 1931 roku. Warto przyjrzeć się, jak artysta rozwiązał te same problemy, które następnie „próbował” opisać i zanalizować jako filozof i teoretyk ekonomii.

Słowa kluczowe: The City of Man, Hermann Broch, Paul Michael Lützeler, Ludwig von Mises, faszyzm. 


\title{
The City of Man and the critique of fascism: The perspective of Hermann Broch
}

\author{
Summary
}

The City of Man initiative, with a conscious reference to Saint Augustine's De civitate Dei, wanted to build a system after the First World War that would ensure free and unfettered human development. This initiative was undertaken by emigrants from Europe and eminent American intellectuals: they all hoped that a realized democracy in the classical Greek sense of the word would not only give us peace, but also open a perspective that, among other things, would eliminate socialism in its fascist and Bolshevik variants.

Why do I open, however, an article devoted to this somewhat forgotten initiative with remarks on the subject of Hermann Broch, who, though he played an important role in the work of this group, was simply "one of many" (exactly one of the seventeen members of the group)? This is due to the fact that his voice was weighty. I also follow Paul Michael Lützeler's suggestions; it must be remembered that the issues raised in the manifesto of the aforementioned group were taken up by the writer and philosopher, from the beginning of his activity, i.e. from his debut in 1931. It is worth looking at how the artist solved the same problems, which he then "tried" to describe and analyze as a philosopher and theoretician of economics.

Keywords: The City of Man, Hermann Broch, Paul Michael Lützeler, Ludwig von Mises, fascism.

Jakub Z. Lichański - professor emeritus, specialist in philosophical sciences (Polish philology, history of literature, popular literature and culture, history, theory and practice of rhetoric). Major publications: Retoryka od średniowiecza do baroku. Teoria i praktyka (1992), Łukasz Górnicki - Sarmacki Castiglione (1998), Retoryka od renesansu do współczesności - tradycja i innowacja (2000), Opowiadania J.R.R. Tolkiena o krawędzi epok i czasów (2003), Retoryka. Historia - teoria - praktyka (2007), "Niobe" K.I. Gałczyńskiego (2015), Filologia - Filozofia - Retoryka. O narzędziach badań (nie tylko) literatury popularnej (2017), Niepopularnie o popularnej. O narzędziach badań literatury (2018). Editor of volumes: Od Oświecenia ku Romantyzmowi. Kultura polska ok. 1800 (1996), J.R.R. Tolkien: recepcja polska (1996), Retoryka i badania literackie (1998), Retoryka i krytyka retoryczna: kom- 
pendium retoryczne (2012). Author of many papers published in, e.g. "Literatura i Kultura Popularna", and in the collected volumes of the "Fantastyczność i cudowność" (Zielona Góra, Poznań) and "POPKultura - POPLiteratura" (Uniwersytet Wrocławski) series. One of the authors of the Historisches Wörterbuch der Rhetorik group. Member of the Polish Philosophical Association, Association of the Friends of History, International Society for the History of Rhetoric, editor-in-chief of Forum Artis Rhetoricae. 